\title{
Ian McKay and Jamie Swift, Warrior Nation: Rebranding Canada in an Age of Anxiety (Toronto: Between the Lines 2012).
}

Canadians are living in a country that is being transformed from a welfare state to a warfare state according to Ian McKay and Jamie Swift's new book, Warrior Nation: Rebranding Canada in an Age of Anxiety. In a year of bicentennial celebrations for the War of 1812, McKay and Swift focus their gaze on the elites in government, military and academia who are actively trying to mobilize Canada's past in service of a militarized present. From the first sentence, these 'new warriors' are chastised for trying to 'rebrand' Canada as a nation "created by wars, defended by soldiers, and kept free by patriotic support of military virtues" (xi). McKay and Swift's work details the ubiquitous ways that Canadian culture is undergoing a process of militarization. Whether it is the inclusion of Afghan veterans at citizenship ceremonies, the recent 'rebranding' of the branches of the Canadian Forces as the 'Royal' Canadian Air Force and 'Royal' Canadian Navy, or the war-heavy Canadian history section of the new citizenship guide, Discover Canada: The Rights and Responsibilities of Citizenship, the Canadian government is shown to be overtly celebrating a militarized vision of Canada's past, present and future.

Unlike the right-wing histories derided in its pages, this book does not try to pluck heroes from Canada's past to challenge Canada's warrior status. Instead, it presents figures who exemplify the complicated and often ambiguous relationship between war and peace in Canada's twentieth century: Bill Stairs, an imperial adventurer and mass-murderer; ELM “Tommy" Burns, Canadian soldier and advocate for disarmament; Lester B. Pearson, the Canadian most closely associated with United Nations peacekeeping but also one of its leading Cold Warriors; and Dr. James Endicott, head of the Canada Peace Congress after the Second World War. McKay and Swift also acknowledge that celebrating Canada's peacekeeping past is not an effective counter to the promotion of Canada as a 'warrior nation.' Instead, they offer up the necessity of Canada breaking the bonds established by the 'passive revolution' that incorporated a progressive desire for democratic change and the promotion of peace into government sponsorship of peacekeeping efforts (295). Antonio Gramsci's concept of reconnaissance informs the structure and content of this book. This should be familiar to those who have read any of McKay's work since his path-breaking "The Liberal Order Framework: A Prospectus for a Reconnaissance of Canadian History" in 2000. By employing the reconnaissance framework, Warrior Nation successfully bridges the fields of foreign policy, political, cultural, and intellectual history that rarely communicate with one another. For scholars who work in Canadian foreign policy, McKay and Swift's work opens new avenues of historical scholarship regarding the attitudes of Canadians toward war and peace in the twentieth century. Their study also encourages a re-examination of the history of 
peacekeeping as a part of Canada's national identity. These themes are central to this book, but there is much that can be done to investigate these issues in more detail. It will be for others to pick up where Warrior Nation leaves off to help us better understand the production, dissemination and reception of messages about war and peace, particularly after the end of World War Two in Canada.

The audience McKay and Swift seek to engage on their polemical road is not limited to foreign policy experts, though. The authors recognize the public nature of memory and commemoration and the dissonances that can exist between what individuals remember and what their government wants them to recall. All Canadian historians are called upon to recognize and challenge those right-wing historians who have gained prominence in the nation's media and who have helped initiate changes in how Canada's past is commemorated. It is far too easy to dismiss the ideas of 'new warriors' as being unrepresentative of current historical thinking or to laugh at their simplistic and macho conceptions of the past. Warrior Nation properly refutes these right-wing conceptions of Canada's history as factually flawed while noting that efforts must be made to reduce the alarming influence of this martial conception of history.

Because this book wears its politics so proudly on its sleeve, it does leave itself open to dismissal from those it seeks to attack. In particular, the choice of the term "Caesarist" to describe the current Harper government seems misplaced (25). Though they make a case for rising authoritarian tendencies by Harper, the book also offers convincing evidence that the Harper government is trying to situate Canada firmly within the sphere of both the past British and current American Empires. If this is so, then Harper can aspire to be little more than a provincial governor rather than a "Caesarist." Ultimately, the subject matter of Warrior Nation is so important that one hopes more conservative historians, as well as those who are inclined to support McKay and Swift's initial premises, will be willing to read all the way through to the end.

McKay and Swift have taken on an expansive topic and a host of historians and government officials in Warrior Nation. Theirs is a call to action that deserves to be widely read and thoroughly discussed.

Colin McCullough

York University

Reinhold Kramer and Tom Mitchell, When the State Trembled: How A.J. Andrews and the Citizens' Committee Broke the Winnipeg General Strike (Toronto: University of Toronto Press, 2010).

When the State Trembled: How A.J. Andrews and the Citizens' Committee Broke the 